\title{
Investigation of the crystal structure of a basic bismuth(III) nitrate with the composition $[\mathrm{Bi6O4}(\mathrm{OH})(4)](0.54(1))[\mathrm{Bi6O5}(\mathrm{OH})(3)](0.46(1))(\mathrm{NO3})(5.54(1))$
}

Christensen, Axel Norlund; Lebech, Bente

Published in:

Dalton Transactions (Print Edition)

Link to article, DOI:

$10.1039 / \mathrm{c} 1 \mathrm{dt} 11646 \mathrm{k}$

Publication date:

2012

Document Version

Publisher's PDF, also known as Version of record

Link back to DTU Orbit

Citation (APA):

Christensen, A. N., \& Lebech, B. (2012). Investigation of the crystal structure of a basic bismuth(III) nitrate with the composition $[\mathrm{Bi} 6 \mathrm{O} 4(\mathrm{OH})(4)](0.54(1))[\mathrm{Bi} 6 \mathrm{O} 5(\mathrm{OH})(3)](0.46(1))(\mathrm{NO} 3)(5.54(1))$. Dalton Transactions (Print Edition), 41(7), 1971-1980. https://doi.org/10.1039/c1dt11646k

\section{General rights}

Copyright and moral rights for the publications made accessible in the public portal are retained by the authors and/or other copyright owners and it is a condition of accessing publications that users recognise and abide by the legal requirements associated with these rights.

- Users may download and print one copy of any publication from the public portal for the purpose of private study or research.

- You may not further distribute the material or use it for any profit-making activity or commercial gain

- You may freely distribute the URL identifying the publication in the public portal 


\title{
Transactions
}

Cite this: Dalton Trans., 2012, 41, 1971

wWW.rsc.org/dalton

PAPER

\section{Investigation of the crystal structure of a basic bismuth(III) nitrate with the composition $\left[\mathrm{Bi}_{6} \mathrm{O}_{4}(\mathrm{OH})_{4}\right]_{0.54(1)}\left[\mathrm{Bi}_{6} \mathrm{O}_{5}(\mathrm{OH})_{3}\right]_{0.46(1)}\left(\mathrm{NO}_{3}\right)_{5.54(1)}$}

\author{
Axel Nørlund Christensen ${ }^{a}$ and Bente Lebech ${ }^{b, c}$ \\ Received 31st August 2011, Accepted 18th October 2011 \\ DOI: 10.1039/c1dt11646k
}

\begin{abstract}
A basic bismuth(III) nitrate with the composition $\left[\mathrm{Bi}_{6} \mathrm{O}_{4}(\mathrm{OH})_{4}\right]_{0.5}\left[\mathrm{Bi}_{6} \mathrm{O}_{5}(\mathrm{OH})_{3}\right]_{0.5}\left(\mathrm{NO}_{3}\right)_{5.5}$ formed in a slow crystal growth mode has an ordered crystal structure with the monoclinic space group $P 2_{1}$ and lattice parameters $a=15.850(3), b=14.986(3), c=18.230(4) \AA, \beta=107.329(17)^{\circ}$ and volume $V=$ 4133.6 $\AA^{3}$ (Henry et al. 2003). In a very fast crystal growth mode the complex ions disorder in another $P 2_{1}$ cell with slightly different lattice parameters $a=15.8404(1), b=15.1982(1), c=18.3122(1) \AA, \beta=$ $106.829(1)^{\circ}$ and $V=4219.8 \AA^{3}$. This cell can be related to two smaller cells: a monoclinic $C 2 / m$ cell with $a=13.7161(1), b=15.1943(1), c=10.2399(1) \AA, \beta=98.586(1)^{\circ}$ and $V=2110.1 \AA^{3}$ and a trigonal $R \overline{3}$ cell with $a=15.18650(6), c=15.8416(1) \AA$ (hexagonal setting) and $V=3164.1 \AA^{3}$. These smaller cells correspond to average structures and hence the X-ray data do not account for the difference in the structures of the two different complex ions. However, when analysing neutron powder diffraction data, it is possible to distinguish between the two complex ions using a trigonal $R \overline{3}$ cell with $a=15.1865(1)$ and $c=15.8416(1) \AA$ (hexagonal setting). In a Rietveld type structure model refinement with a total of 28 atom sites $(4 \mathrm{Bi}, 3 \mathrm{~N}, 15 \mathrm{O}$ and $6 \mathrm{H})$, the composition of this sample is determined to be $\left[\mathrm{Bi}_{6} \mathrm{O}_{4}(\mathrm{OH})_{4}\right]_{0.54(1)}\left[\mathrm{Bi}_{6} \mathrm{O}_{5}(\mathrm{OH})_{3}\right]_{0.46(1)}\left(\mathrm{NO}_{3}\right)_{5.54(1)}$.
\end{abstract}

\section{Introduction}

In crystallisation and crystal growth of a compound, the smaller crystals are usually formed in a fast growth mode and the larger ones in a slow growth mode. Normally, the same crystalline phase is obtained in the two cases. However, variations in temperature, the $\mathrm{pH}$ of the solutions or other experimental conditions may result in the formation of two or more different crystalline phases of the compound. The chemistry of basic bismuth(III) nitrate has a case where the crystal preparation mode can result in two different structures of the compound, one with an ordered packing of the ions, and one with a disordered packing of the ions. This is found to be the case for the basic bismuth(III) nitrate with the general chemical formula $\left[\mathrm{Bi}_{6} \mathrm{O}_{4}(\mathrm{OH})_{4}\right]_{0.5+x}\left[\mathrm{Bi}_{6} \mathrm{O}_{5}(\mathrm{OH})_{3}\right]_{0.5-x}\left(\mathrm{NO}_{3}\right)_{5.5+x}$, which contains two different complex ions, $\left[\mathrm{Bi}_{6} \mathrm{O}_{4}(\mathrm{OH})_{4}\right]^{6+}$ and $\left[\mathrm{Bi}_{6} \mathrm{O}_{5}(\mathrm{OH})_{3}\right]^{5+}$.

The basic bismuth(III) nitrates are formed in hydrolyses of bismuth(III) nitrate pentahydrate $\mathrm{Bi}\left(\mathrm{NO}_{3}\right)_{3} \cdot 5 \mathrm{H}_{2} \mathrm{O}$, and have been known for at least two centuries with the trade names Magisterium bismuti and Bismutum subnitricum. They have had medical applications as mild anticeptics. ${ }^{1,2}$ The compositions of some of these basic bismuth(III) nitrates have in the past been established from chemical analysis and X-ray single crystal structure analysis,

${ }^{a}$ Crystal Chemistry, Højkolvej 7, DK-8210 Arhus V, Denmark

${ }^{b}$ Niels Bohr Institute, University of Copenhagen, DK-2100 Copenhagen, Denmark

'Materials Research Division, Risø DTU, Technical University of Denmark, Frederiksborgvej 399, Dk-4000 Roskilde, Denmark
Table 1 The basic bismuth(III) nitrates. Composition and published Xray powder patterns. The short names were introduced in a previous investigation $^{7}$

\begin{tabular}{llll}
\hline Compound & $\begin{array}{l}\text { Batch or } \\
\text { short name }\end{array}$ & ICDD cards & Reference \\
\hline$\left[\mathrm{Bi}_{6} \mathrm{O}_{4}(\mathrm{OH})_{4}\right]\left(\mathrm{NO}_{3}\right)_{6} \cdot 4 \mathrm{H}_{2} \mathrm{O}$ & $\mathrm{C}$ & $84-2189$ & 3 \\
{$\left[\mathrm{Bi}_{6} \mathrm{O}_{4}(\mathrm{OH})_{4}\right]\left(\mathrm{NO}_{3}\right)_{6} \cdot \mathrm{H}_{2} \mathrm{O}$} & $\mathrm{D}$ & $71-1360,70-2235$ & 4,5 \\
{$\left[\mathrm{Bi}_{6} \mathrm{O}_{5}(\mathrm{OH})_{3}\right]\left(\mathrm{NO}_{3}\right)_{5} \cdot 3 \mathrm{H}_{2} \mathrm{O}$} & $\mathrm{A}$ & $70-1226$ & 6 \\
{$\left[\mathrm{Bi}_{6} \mathrm{O}_{5}(\mathrm{OH})_{3}\right]\left(\mathrm{NO}_{3}\right)_{5} \cdot 2 \mathrm{H}_{2} \mathrm{O}$} & $\mathbf{X}$ & & $7^{a}$ \\
{$\left[\mathrm{Bi}_{6} \mathrm{O}_{4.5}(\mathrm{OH})_{3.5}\right]\left(\mathrm{NO}_{3}\right)_{5.5} \cdot \mathrm{H}_{2} \mathrm{O}$} & $\mathbf{X}$ & & $8^{a}$ \\
{$\left[\mathrm{Bi}_{6} \mathrm{O}_{4.5}(\mathrm{OH})_{3.5}\right]_{2}\left(\mathrm{NO}_{3}\right)_{11}$} & & $01-072-7618$ & 9 \\
{$\left[\mathrm{Bi}_{6} \mathrm{O}_{4}(\mathrm{OH})_{4}\right]\left(\mathrm{NO}_{3}\right)_{6}$} & & & 10
\end{tabular}

${ }^{a}$ The present investigation has led to the conclusion that batch-X samples do not contain $\mathrm{H}_{2} \mathrm{O}$ (see section 1).

and some X-ray powder patterns of them are reported in the ICDD data base, see Tables 1 and $2 .^{3-10}$

The crystal structure investigations ${ }^{3-10}$ showed that these compounds may contain the two complex ions $\left[\mathrm{Bi}_{6} \mathrm{O}_{4}(\mathrm{OH})_{4}\right]^{6+}$ and $\left[\mathrm{Bi}_{6} \mathrm{O}_{5}(\mathrm{OH})_{3}\right]^{5+}$. The compounds listed in Tables 1 and 2 are formed in acid media where the equilibrium shown in eqn 1

$$
\left[\mathrm{Bi}_{6} \mathrm{O}_{4}(\mathrm{OH})_{4}\right]^{6+}+\mathrm{H}_{2} \mathrm{O}=\left[\mathrm{Bi}_{6} \mathrm{O}_{5}(\mathrm{OH})_{3}\right]^{5+}+\mathrm{H}_{3} \mathrm{O}^{+}
$$

is $\mathrm{pH}$ dependent, so that a low $\mathrm{pH}$ level favours the formation of the compounds $\left[\mathrm{Bi}_{6} \mathrm{O}_{4}(\mathrm{OH})_{4}\right]\left(\mathrm{NO}_{3}\right)_{6} \cdot y \mathrm{H}_{2} \mathrm{O}(y=1$ and 4$)$, and a slightly higher $\mathrm{pH}$ level results in the formation of the compound $\left[\mathrm{Bi}_{6} \mathrm{O}_{5}(\mathrm{OH})_{3}\right]\left(\mathrm{NO}_{3}\right)_{5} \cdot 3 \mathrm{H}_{2} \mathrm{O}$. Summaries of the synthetic routes for 
Table 2 Unit cell dimensions for the compounds listed in Table 1

\begin{tabular}{|c|c|c|c|c|c|c|}
\hline Ref. & $a / \AA$ & $b / \AA$ & $c / \AA ̊$ & $\beta\left(^{\circ}\right)$ & Volume $/ \AA^{3}$ & Space group \\
\hline 3 & $9.059(4)$ & $17.050(2)$ & $18.269(2)$ & $120.00(1)$ & 2443.7 & $P 2_{1} / c$ \\
\hline 4 & $9.313(2)$ & $13.514(7)$ & $19.575(5)$ & $114.12(1)$ & 2248.5 & $P 2_{1} / c$ \\
\hline 6 & $17.152(1)$ & $9.181(1)$ & $17.752(1)$ & $127.830(7)$ & 2207.9 & $P 2_{1} / c$ \\
\hline 7 & $10.237(2)$ & $7.592(2)$ & $6.863(2)$ & $98.65(2)$ & 527.3 & Monoclinic $^{a}$ \\
\hline 7 & $15.185(1)$ & $15.185(1)$ & $15.834(2)$ & & 3161.9 & $R \overline{3}$ \\
\hline 9 & $15.850(3)$ & $14.986(3)$ & $18.230(4)$ & $107.329(17)$ & 4133.7 & $P 2_{1}$ \\
\hline
\end{tabular}

${ }^{a}$ Equivalent to $C 2 / m$ in this work.

the formation of the basic bismuth(III) nitrates can be found in the literature. ${ }^{11}$

During an investigation of homogeneous hydrolyses by the use of aqueous solutions of urea, ${ }^{12}$ it was observed that a homogeneous hydrolysis of bismuth(III) nitrate resulted in the formation of a crystalline compound called batch-X. ${ }^{7}$ Chemical analyses indicated that this compound could have the composition $\left[\mathrm{Bi}_{6} \mathrm{O}_{5}(\mathrm{OH})_{3}\right]\left(\mathrm{NO}_{3}\right)_{5} \cdot 2 \mathrm{H}_{2} \mathrm{O}$, but a subsequent analysis resulted in the composition $\left[\mathrm{Bi}_{6} \mathrm{O}_{4.5}(\mathrm{OH})_{3.5}\right]\left(\mathrm{NO}_{3}\right)_{5.5} \cdot \mathrm{H}_{2} \mathrm{O}{ }^{8}$ The thermogravimetric analysis of batch-X material showed a loss in weight after transformation to $\alpha-\mathrm{Bi}_{2} \mathrm{O}_{3}$ of $19.4 \%$, which was in accord with the loss of $19.2 \%$ for a compound with the composition $\left[\mathrm{Bi}_{6} \mathrm{O}_{5}(\mathrm{OH})_{3}\right]\left(\mathrm{NO}_{3}\right)_{5} \cdot 2 \mathrm{H}_{2} \mathrm{O} .^{7}$ However, this contrasted with a repeated chemical analysis of batch-X material for $\mathrm{Bi}$ and $\mathrm{NO}_{3}{ }^{-}$, which resulted in $71.79 \% \mathrm{Bi}$ and $19.5 \% \mathrm{NO}_{3}^{-}$in good agreement with the composition $\left[\mathrm{Bi}_{6} \mathrm{O}_{4.5}(\mathrm{OH})_{3.5}\right]\left(\mathrm{NO}_{3}\right)_{5.5} \cdot \mathrm{H}_{2} \mathrm{O}^{8}$ Interpretations of the NMR patterns supported that batch-X could possibly contain water. This is in conflict with the fact that the loss in weight to $\alpha-\mathrm{Bi}_{2} \mathrm{O}_{3}$ is expected to be $19.7 \%$ and $19.0 \%$ for $\left[\mathrm{Bi}_{6} \mathrm{O}_{4.5}(\mathrm{OH})_{3.5}\right]\left(\mathrm{NO}_{3}\right)_{5.5} \cdot \mathrm{H}_{2} \mathrm{O}$ and $\left[\mathrm{Bi}_{6} \mathrm{O}_{4.5}(\mathrm{OH})_{3.5}\right]\left(\mathrm{NO}_{3}\right)_{5.5}$, respectively, which (within the accuracy of the analyses) indicates that the assignment of chemical composition to batch-X would have to be a choice between these two chemical formulas. Therefore, because the present neutron diffraction crystal structure analyses do not indicate any water content in batch-X material, it is concluded that these samples are without water of crystallisation.

A synchrotron X-ray powder pattern of a batch-X sample was indexed in a trigonal cell using hexagonal setting with the unit cell $a=15.185(1), c=15.834(2) \AA$ and the space group $R \overline{3} .^{7}$ Dependent upon how many very weak reflections were used in the indexing calculations, ${ }^{7,8}$ the data could also be indexed with a monoclinic cell with $a=10.237(2), b=7.592(2), c=6.863(2) \AA$ and $\beta=98.65(2)^{\circ} .^{7} \mathrm{~A}$ number of attempts to solve the structure of samples from batch-X using synchrotron X-ray single crystal and powder diffraction data ${ }^{7,8}$ failed when using the trigonal cell, because unrealistically short $\mathrm{Bi}-\mathrm{Bi}$ distances $(1.83-2.28 \AA$ ) were obtained.

Subsequently, two crystal structure investigations on basic bismuth(III) nitrates, $\left[\mathrm{Bi}_{6} \mathrm{O}_{4.5}(\mathrm{OH})_{3.5}\right]_{2}\left(\mathrm{NO}_{3}\right)_{11}{ }^{9}$ and $\left[\mathrm{Bi}_{6} \mathrm{O}_{4}(\mathrm{OH})_{4}\right]-$ $\left(\mathrm{NO}_{3}\right)_{6},{ }^{10}$ have been published by Henry et al. The model of the first structure ${ }^{9}$ has a monoclinic unit cell, $a=15.850(3), b=$ $14.986(3), c=18.230(4) \AA, \beta=107.329(17)^{\circ}$ and the space group $P 2_{1}$. The chemical formula of this compound corresponds to the general formula: $\left[\mathrm{Bi}_{6} \mathrm{O}_{4}(\mathrm{OH})_{4}\right]_{0.5+x}\left[\mathrm{Bi}_{6} \mathrm{O}_{5}(\mathrm{OH})_{3}\right]_{0.5-x}\left(\mathrm{NO}_{3}\right)_{5.5+x}$ with $x=0.0$. The model contains four independent $\mathrm{Bi}_{6}$-octahedra or a total of 24 independent $\mathrm{Bi}$-atoms. The calculated powder pattern of $\left[\mathrm{Bi}_{6} \mathrm{O}_{4.5}(\mathrm{OH})_{3.5}\right]_{2}\left(\mathrm{NO}_{3}\right)_{11}(\mathrm{ICDD}$ card no. 01-072-7618) has 199 reflections in the $d$-spacing range 17.40-2.271 $\AA$, including a large number of weak and not well resolved peaks.

The model of the second structure ${ }^{10}$ has a trigonal unit cell, $a=$ 15.1332(6) and $c=15.7909$ (9) $\AA$ (hexagonal setting) and the space group $R \overline{3}$. The chemical formula of that compound corresponds to the general formula: $\left[\mathrm{Bi}_{6} \mathrm{O}_{4}(\mathrm{OH})_{4}\right]_{0.5+x}\left[\mathrm{Bi}_{6} \mathrm{O}_{5}(\mathrm{OH})_{3}\right]_{0.5-x}\left(\mathrm{NO}_{3}\right)_{5.5+x}$ with $x=0.5$. It contains six $\left[\mathrm{Bi}_{6} \mathrm{O}_{4}(\mathrm{OH})_{4}\right]^{6+}$ ions packed into the structure and in addition six other $\left[\mathrm{Bi}_{6} \mathrm{O}_{4}(\mathrm{OH})_{4}\right]^{6+}$ ions packed close to the first set of ions in a complex way, resulting in very short $\mathrm{Bi}-\mathrm{Bi}$ distances (Bi1a-Bi2a $=1.724$ and $2.334 \AA$; $\mathrm{Bi} 1 \mathrm{~b}-\mathrm{Bi} 2 \mathrm{~b}=$ 1.795 and $2.398 \AA),{ }^{10}$ which indicates that the structure could be disordered or contains stacking faults.

From a comparison between the patterns calculated by means of the model parameters listed in Ref. 9 and 10, it is evident that the structure of $\left[\mathrm{Bi}_{6} \mathrm{O}_{4.5}(\mathrm{OH})_{3.5}\right]_{2}\left(\mathrm{NO}_{3}\right)_{11}{ }^{9}$ differs from that of $\left[\mathrm{Bi}_{6} \mathrm{O}_{4}(\mathrm{OH})_{4}\right]\left(\mathrm{NO}_{3}\right)_{6} \cdot{ }^{10}$ The observed synchrotron X-ray powder pattern of the batch-X sample $\left[\mathrm{Bi}_{6} \mathrm{O}_{4.5}(\mathrm{OH})_{3.5}\right]\left(\mathrm{NO}_{3}\right)_{5.5} \cdot \mathrm{H}_{2} \mathrm{O}^{7,8}$ was apparently almost identical to the calculated pattern of $\left[\mathrm{Bi}_{6} \mathrm{O}_{4}(\mathrm{OH})_{4}\right]\left(\mathrm{NO}_{3}\right)_{6},{ }^{10}$ with 24 well resolved reflections in the $d$-spacing range 7.597-2.262 $\AA$. However, because a similar model had already been explored and rejected in the previous investigations of batch-X samples, ${ }^{7,8}$ (see above) it seemed relevant to consider other probable model structures of the group of compounds with the general formula $\left[\mathrm{Bi}_{6} \mathrm{O}_{4}(\mathrm{OH})_{4}\right]_{0.5+x}\left[\mathrm{Bi}_{6} \mathrm{O}_{5}(\mathrm{OH})_{3}\right]_{0.5-x}\left(\mathrm{NO}_{3}\right)_{5.5+x}$.

As a starting point, the following hypotheses will be tested:

- The model of the structure of $\left[\mathrm{Bi}_{6} \mathrm{O}_{4}(\mathrm{OH})_{4}\right]\left(\mathrm{NO}_{3}\right)_{6}{ }^{10}$ is related to that of $\left[\mathrm{Bi}_{6} \mathrm{O}_{4.5}(\mathrm{OH})_{3.5}\right]_{2}\left(\mathrm{NO}_{3}\right)_{11} \cdot{ }^{9}$

- The two compounds reported as $\left[\mathrm{Bi}_{6} \mathrm{O}_{4.5}(\mathrm{OH})_{3.5}\right]\left(\mathrm{NO}_{3}\right)_{5.5} \cdot \mathrm{H}_{2} \mathrm{O}^{8}$ and $\left[\mathrm{Bi}_{6} \mathrm{O}_{4}(\mathrm{OH})_{4}\right]\left(\mathrm{NO}_{3}\right)_{6}{ }^{10}$ have almost identical powder patterns and are assumed to be related.

- The compounds reported as $\left[\mathrm{Bi}_{6} \mathrm{O}_{4.5}(\mathrm{OH})_{3.5}\right]\left(\mathrm{NO}_{3}\right)_{5.5} \cdot \mathrm{H}_{2} \mathrm{O},{ }^{8}$ $\left[\mathrm{Bi}_{6} \mathrm{O}_{4.5}(\mathrm{OH})_{3.5}\right]_{2}\left(\mathrm{NO}_{3}\right)_{11}{ }^{9}$ and $\left[\mathrm{Bi}_{6} \mathrm{O}_{4}(\mathrm{OH})_{4}\right](\mathrm{NO} 3)_{6}{ }^{10}$ may all be described as structures containing $\left[\mathrm{Bi}_{6} \mathrm{O}_{4}(\mathrm{OH})_{4}\right]^{6+}$ ions and $\left[\mathrm{Bi}_{6} \mathrm{O}_{5}(\mathrm{OH})_{3}\right]^{5+}$ ions in an ordered or a disordered arrangement.

Below, section 2 presents the X-ray and neutron diffraction data for samples of batch-X material followed, in section 3 , by model considerations that are important when testing if these hypotheses are valid or not. The final data analyses related to these models are presented in section 4 and summary and conclusion in section 5 . 
Table 3 Unit cell parameters obtained in the indexing of patterns and refinement of the unit cells (this work)

\begin{tabular}{|c|c|c|c|c|c|c|c|c|}
\hline Pattern/sample & Technique & $a / \AA ̊$ & $b / \AA ̊$ & $c / \AA ̊$ & $\beta\left(^{\circ}\right)$ & Volume $/ \AA^{3}$ & Space group & Program/case \\
\hline \multirow[t]{5}{*}{$1 / X$} & \multirow[t]{5}{*}{ X-ray, powder } & $15.1865(1)$ & $15.1865(1)$ & $15.8416(1)$ & & 3164.1 & $R \overline{3}$ & FullProf/A \\
\hline & & $15.8404(2)$ & $15.1982(1)$ & $18.3122(1)$ & $106.829(1)$ & 4219.8 & $P 2_{1}$ & FullProf/B \\
\hline & & $13.7154(2)$ & $15.1928(1)$ & $20.4696(5)$ & $98.502(1)$ & 4218.5 & $P 2_{1}$ & FullProf/C \\
\hline & & 13.7161(1) & $15.1943(1)$ & $10.2399(1)$ & $98.586(1)$ & 2110.1 & $C 2 / m$ & FullProf/D \\
\hline & & $6.837(1)$ & $15.186(1)$ & $10.235(1)$ & $98.66(2)$ & 1050.6 & $P 2_{1}$ & DICVOL04 \\
\hline \multirow[t]{4}{*}{$2 / X$} & \multirow[t]{4}{*}{ neutron, powder } & $15.1846(6)$ & $15.1846(6)$ & $15.8470(5)$ & & 3164.4 & $R \overline{3}$ & FullProf \\
\hline & & $13.742(1)$ & $15.153(1)$ & $20.522(1)$ & $98.62(1)$ & 4114.1 & $P 2_{1}$ & FullProf \\
\hline & & $6.849(2)$ & $7.589(2)$ & $10.236(1)$ & $98.61(2)$ & 526.0 & $P 2_{1}$ & DICVOL04 \\
\hline & & 13.745 & 15.183 & 10.257 & 98.275 & 2118.3 & $P 2_{1}$ & ITO \\
\hline \multirow[t]{3}{*}{$3 / \mathrm{X}^{a}$} & \multirow[t]{3}{*}{ X-ray, powder } & $15.200(1)$ & $15.200(1)$ & $15.863(1)$ & & 3174.0 & $R \overline{3}$ & FullProf \\
\hline & & $15.8933(5)$ & $14.3337(7)$ & $18.297(1)$ & $106.95(5)$ & 3987.2 & $P 2_{1}$ & FullProf \\
\hline & & $13.168(1)$ & $15.1964(5)$ & $20.585(1)$ & $98.23(1)$ & 4076.8 & $P 2_{1}$ & FullProf \\
\hline $4 / X$ & X-ray, crystal HASYLAB & 15.1797 & 15.1797 & 15.8364 & & 3160.2 & $R \overline{3}$ & /SC-1 \\
\hline $5 / \mathrm{X}$ & X-ray, crystal X7B NSLS & $13.716(3)$ & $15.176(3)$ & $10.225(3)$ & $98.60(3)$ & 2104.4 & $C 2 / m$ & $/ \mathrm{SC}-2$ \\
\hline
\end{tabular}

\section{Experimental}

The chemicals used when making the batches of bismuth(III) nitrate prepared for the present investigation were routinely checked by collecting X-ray diffraction patterns using a StoeStadie diffractometer with $\mathrm{CuK}_{\alpha 1}$ radiation, $\lambda=1.540598 \AA$. The produced samples were checked in the same way and the patterns were indexed with the programs DICVOL0 $4^{13}$ and $\mathrm{ITO}^{14}$ in order to confirm that the samples used were all batch-X samples. Refinements of the unit cell parameters were then made using the program FullProf ${ }^{15}$ in the profile matching mode (Le Bail type matching). Several samples were prepared and used to collect better data, which were used in the crystal structure analyses presented in section 4 . The final data consisted of two synchrotron $\mathrm{X}$-ray powder diffraction patterns, one neutron powder diffraction pattern and two sets of independent single crystal synchrotron Xray diffraction data as listed below.

\section{Powder pattern 1}

A synchrotron X-ray powder pattern was recorded at $25^{\circ} \mathrm{C}$ on the Swiss Norwegian beam line at ESRF using a wavelength $\lambda=$
$1.0982 \AA$ and covering the $2 \theta$ range from $8.00^{\circ}$ to $56.80^{\circ}$ in steps of $0.01^{\circ} .^{7}$ The pattern is shown in Fig. 1. It can be indexed in a trigonal and three monoclinic unit cells with refined cell parameters as listed in Table 3.

\section{Powder pattern 2}

A neutron powder diffraction pattern was recorded at $25^{\circ} \mathrm{C}$ using the diffractometer D2B at ILL using a wavelength $\lambda=1.4949 \AA$ and covering the $2 \theta$ range from $11.065^{\circ}$ to $155.915^{\circ}$ in steps of $0.050^{\circ}$. The values found by indexing and subsequent refinements of the unit cell parameters are listed in Table 3. This pattern is shown Fig. 2 and it can also be indexed in a trigonal and three monoclinic unit cells.

\section{Powder pattern 3}

A synchrotron X-ray powder pattern was recorded on the diffractometer at the beam line X7B at NSLS Brookhaven National Laboratory in an in situ experiment where a mixture of $\left[\mathrm{Bi}_{6} \mathrm{O}_{5}(\mathrm{OH})_{3}\right]\left(\mathrm{NO}_{3}\right)_{5} \cdot 3 \mathrm{H}_{2} \mathrm{O}$ and urea was converted hydrothermally to a batch-X material, and finally to $\mathrm{Bi}_{2} \mathrm{O}_{2} \mathrm{CO}_{3}{ }^{8}$ The

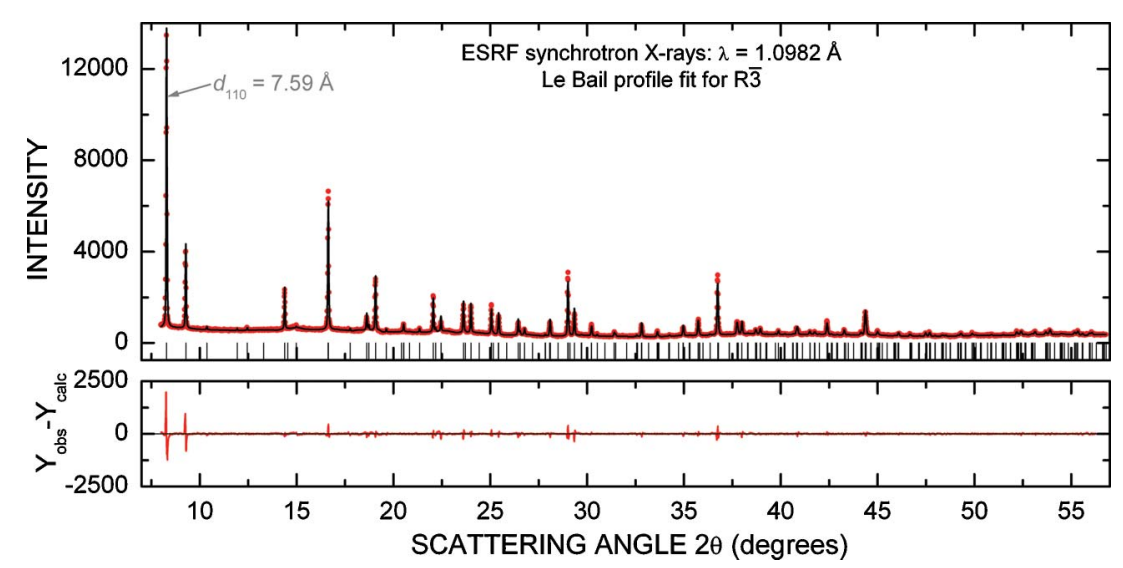

Fig. 1 The synchrotron X-ray powder diffraction pattern of a batch-X sample recorded at $25^{\circ} \mathrm{C}$. The figure shows at the top: (๑) observed and (-) calculated patterns, and below: the difference (_). The vertical ticks mark the Bragg peak positions. Using FullProf ${ }^{15}$ in the profile matching mode (Le Bail fit) with the $R \overline{3}$ space group resulted in $\chi^{2}=2.9, R_{\mathrm{Bragg}}=0.12 \%, R_{\mathrm{F}}=0.25 \%$ and profile parameters $U=0.031(3), V=-0.005(1), W=0.0011(1)$ and $Y=0.0258(4)$. The position of the first Bragg reflection observed in this pattern with $d_{110}=7.59 \AA$ is marked. For further details see the text and Table 3 . 


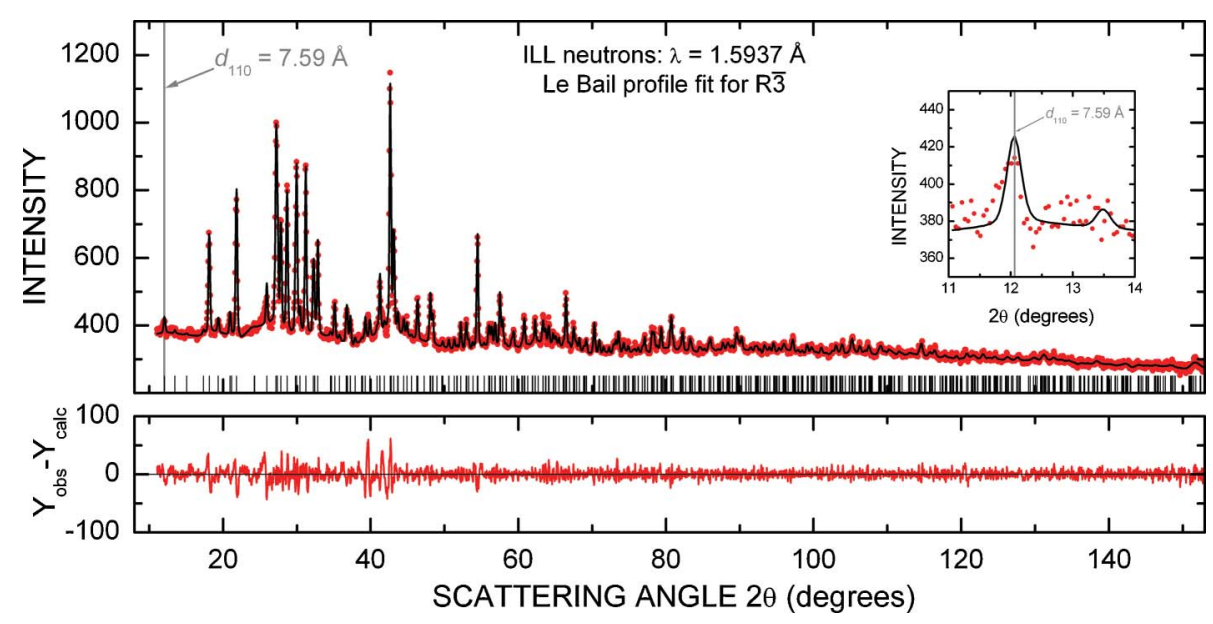

Fig. 2 Neutron powder diffraction pattern of a batch-X sample recorded at $25^{\circ} \mathrm{C}$. The figure shows at the top (๑) observed and ( - ) calculated patterns and below the difference (_). The vertical ticks mark the Bragg peak positions. Using FullProf ${ }^{15}$ in the profile matching mode (Le Bail fit) with the $R \overline{3}$ space group resulted in $\chi^{2}=1.4, R_{\mathrm{Bragg}}=0.27 \% R_{\mathrm{F}}=0.40 \%$ and profile parameters $U=0.08(1), V=-0.09(1), W=0.060(3)$ and $Y=0.082(3)$. The position of the first Bragg reflection observed in this pattern with $d_{110}=7.59 \AA$ is marked and shown on expanded scales in the inset. For further details see the text and Table 3.

wavelength was $\lambda=0.9022 \AA$ covering a $2 \theta$ range from $3.0033^{\circ}$ to $44.9902^{\circ}$ in $0.0196^{\circ}$ increments. The selected pattern recorded at $100{ }^{\circ} \mathrm{C}$ had a weak low angle reflection at $2 \theta=5.107^{\circ}$ corresponding to a $d$-spacing of $10.13 \AA$. This reflection was not observed in powder patterns 1 and 2 , because these patterns did not include the corresponding low angle regions. The pattern 3 can be indexed in a trigonal and two monoclinic cells with refined unit cell parameters listed in Table 3. Pattern 3 may also be indexed in the trigonal cell of pattern 1, but with a different zero offset and a slightly larger $\chi^{2}$. The diffraction data for pattern 3 is displayed in Fig. $3 \mathrm{~b}$ as a function of scattering vector length $|q|=2 \pi / d=4 \pi \sin (\theta) / \lambda$ in order to allow direct comparison with the corresponding data for patterns 1 (3a) and 2 (3c).

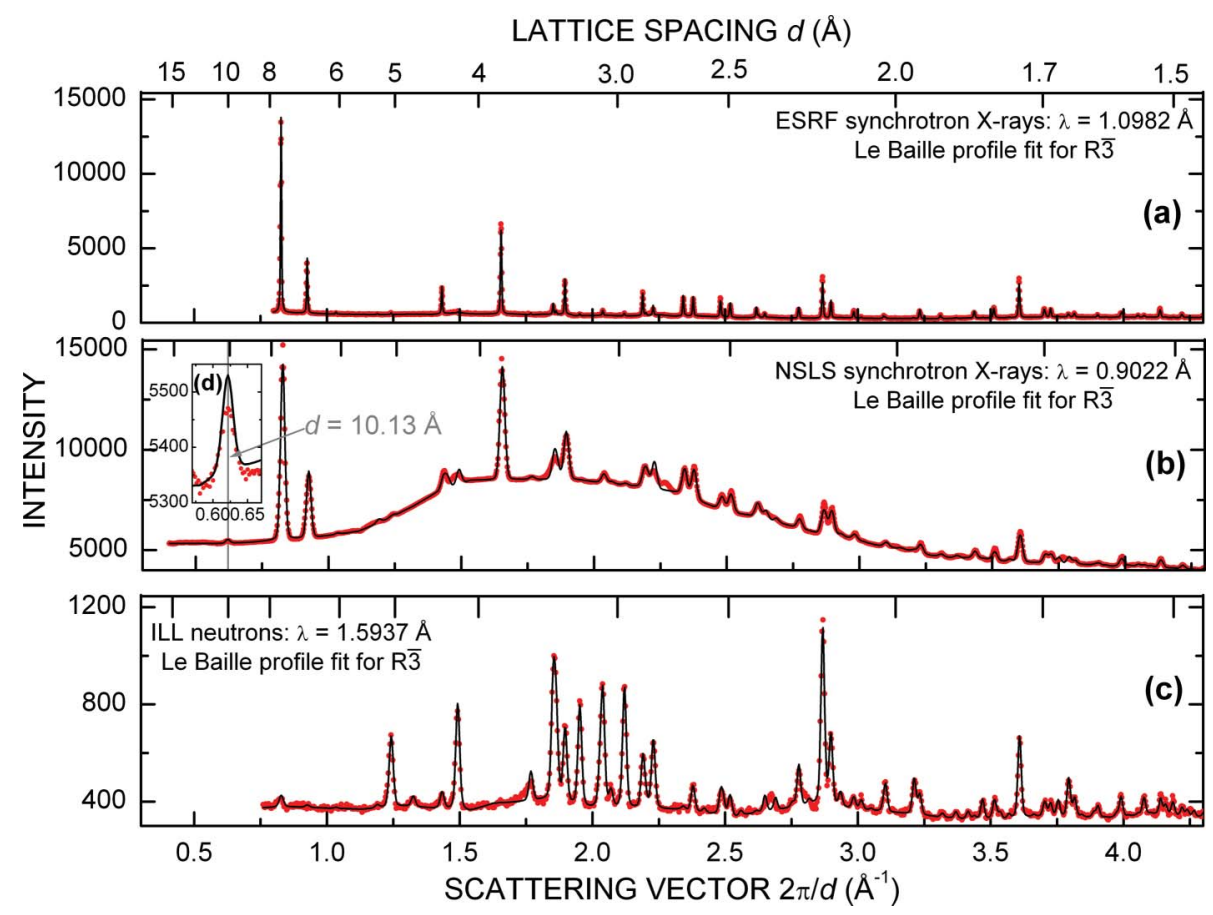

Fig. 3 Powder diffraction patterns of batch-X samples displayed as intensity $v s$. scattering vector length $|q|=2 \pi /|d|=4 \pi \sin (\theta) / \lambda$. The data in (a) and (c) is X-ray and neutron data recorded at $25^{\circ} \mathrm{C}$, respectively, while the data in (b) is X-ray data recorded at $100{ }^{\circ} \mathrm{C}$ (see text for an explanation). The figure shows the (๑) observed and (-) calculated patterns. Using FullProf ${ }^{15}$ in the profile matching mode (Le Bail fit) for the data in (b) with the $R \overline{3}$ space group resulted in $\chi^{2}=0.9, R_{\mathrm{Bragg}}=0.19 \%, R_{\mathrm{F}}=0.29 \%$ and profile parameters $U=-0.55(3), V=0.21(1), W=0.011(1)$ and $Y=0.024(2)$. The position of the first Bragg reflection observed in this pattern with $d_{101}=10.13 \AA$ is marked and shown on an expanded intensity scale in the inset (d). For further details see captions to Fig. 1 and 2, the text and Table 3. 


\section{Single crystal data}

Two sets of single crystal synchrotron X-ray diffraction data were collected and they agree with the results from the powder diffraction data. Data set SC-1 was recorded on a diffractometer at HASYLAB, Hamburg using the wavelength $\lambda=0.5627 \AA$. Data set SC-2 was recorded on a diffractometer at the beam line X7B at NSLS Brookhaven National Laboratory using the wavelength $\lambda=0.9269 \AA$. The unit cells used in these measurements are also listed in Table 3. At HASYLAB a trigonal cell was used, and at NSLS Brookhaven a monoclinic cell. Both data sets were recorded at $25^{\circ} \mathrm{C}$.

\section{Space group, unit cells and possible structure models}

\subsection{Space group determination in the case of a heavy atom structure}

It should be noted that, for these compounds, the determination of the space group and crystal structure from X-ray diffraction is that of a typical heavy atom structure analysis because the scattering is dominated by the scattering contributions from the Bi atoms. A possible pitfall is therefore to overlook very weak reflections in the determination of unit cell and space group when analysing data from both powder and single crystal diffractometers. The result may well be that the unit cell is determined too small and hence that the space group is determined incorrectly. Thus, the cell used in the X7B NSLS measurements had a volume only half that of the original monoclinic cell found for the $\left[\mathrm{Bi}_{6} \mathrm{O}_{4.5}(\mathrm{OH})_{3.5}\right]_{2}\left(\mathrm{NO}_{3}\right)_{11}{ }^{9}$ structure (Table 1). Furthermore, the two independent acquisitions of single crystal data from batch-X crystals resulted in assignments of a trigonal space group for one of the crystals and a monoclinic space group for the other crystal. Similar conflicting results were obtained when indexing the powder diffraction patterns (see Table 3), e.g. the very small cells found when using DICVOL04. ${ }^{13} \mathrm{~A}$ significant evidence of the fact that these smaller unit cells are incorrect is the observation of the Bragg peak at $d \sim 10 \AA$ in pattern 3 (Fig. $3 \mathrm{~b}$ and $3 \mathrm{~d}$ ). In the Le Baille profile matching fits this peak would correspond to $d_{101}=10.130 \AA$ in space group $R \overline{3}$ or to the overlapping peaks at $d_{002}=10.143 \AA$ and $d_{110}=9.872 \AA$ with intensity ratio $\sim 10: 1$ in space group $P 2_{1}$.

The crystal structures of the compounds listed in Table 1 may all be described in the monoclinic space groups, except for the structure of $\left[\mathrm{Bi}_{6} \mathrm{O}_{4}(\mathrm{OH})_{4}\right]\left(\mathrm{NO}_{3}\right)_{6} \cdot{ }^{10}$ They contain four or eight of the complex $\mathrm{Bi}$ ions. Only $\left[\mathrm{Bi}_{6} \mathrm{O}_{4}(\mathrm{OH})_{4}\right]\left(\mathrm{NO}_{3}\right)_{6}$ is described in the trigonal space group $R \overline{3}$, and contains a total of six complex $\mathrm{Bi}_{6}$ octahedra. A relevant question to ask is therefore: can the $R \overline{3}$ structure be related to the monoclinic structure described in the space group $P 2_{1} ?^{9}$ In the following, several structural models are considered in order to answer this question.

3.2.1. The published structure model with an ordered arrangement of the complex Bi-ions. The sample used in the published structure investigation of $\left[\mathrm{Bi}_{6} \mathrm{O}_{4.5}(\mathrm{OH})_{3.5}\right]_{2}\left(\mathrm{NO}_{3}\right)_{11}{ }^{9}$ was made from $\left[\mathrm{Bi}_{6} \mathrm{O}_{5}(\mathrm{OH})_{3}\right]\left(\mathrm{NO}_{3}\right)_{5} \cdot 3 \mathrm{H}_{2} \mathrm{O}$ partly dissolved in water. The crystals were precipitated from the solution in a slow evaporation. In the present study it was not possible to obtain crystals of $\left[\mathrm{Bi}_{6} \mathrm{O}_{4.5}(\mathrm{OH})_{3.5}\right]_{2}\left(\mathrm{NO}_{3}\right)_{11}$ following the procedure reported in Ref. 9 The equilibrium mentioned in eqn (1) will result in the formation of the two complex ions $\left[\mathrm{Bi}_{6} \mathrm{O}_{4}(\mathrm{OH})_{4}\right]^{6+}$ and $\left[\mathrm{Bi}_{6} \mathrm{O}_{5}(\mathrm{OH})_{3}\right]^{5+}$, and the $\mathrm{pH}$ of the solution ${ }^{9}$ must have had a level ensuring that the ions were present in sufficient concentration for a slow crystal growth and an ordered arrangement of the ions. The crystals so formed contained four of each of the two ions. The composition of the compound would then correspond to the general formula: $\left[\mathrm{Bi}_{6} \mathrm{O}_{4}(\mathrm{OH})_{4}\right]_{0.5+x}\left[\mathrm{Bi}_{6} \mathrm{O}_{5}(\mathrm{OH})_{3}\right]_{0.5-x}\left(\mathrm{NO}_{3}\right)_{5.5+x}$ with $x=0.0$. The structure is ordered in a stoichiometric composition with respect to the two different complex Bi-ions. The crystal structure investigation ${ }^{9}$ resulted in a monoclinic $P 2_{1}$ structure with a hydrogen bond between the two complex ions $\mathrm{O} 15-\mathrm{H}-\mathrm{O} 25$ and corresponding bonds for the three other $\mathrm{Bi}_{6}$-ion pairs (see the text related to Fig. 4 in Ref. 9). Although it is plausible that there are two Bi-complexes in this structure, it was not possible to determine which Bi-complex has the charge $6+$ and which has $5+$. Hence, the composition is an average composition, and the crystal structure refinement only revealed the positions of an average ion $\left[\mathrm{Bi}_{6} \mathrm{O}_{4.5}(\mathrm{OH})_{3.5}\right]^{5.5+}$. However, the structure is ordered in the sense that the Bi-complexes do not overlap.

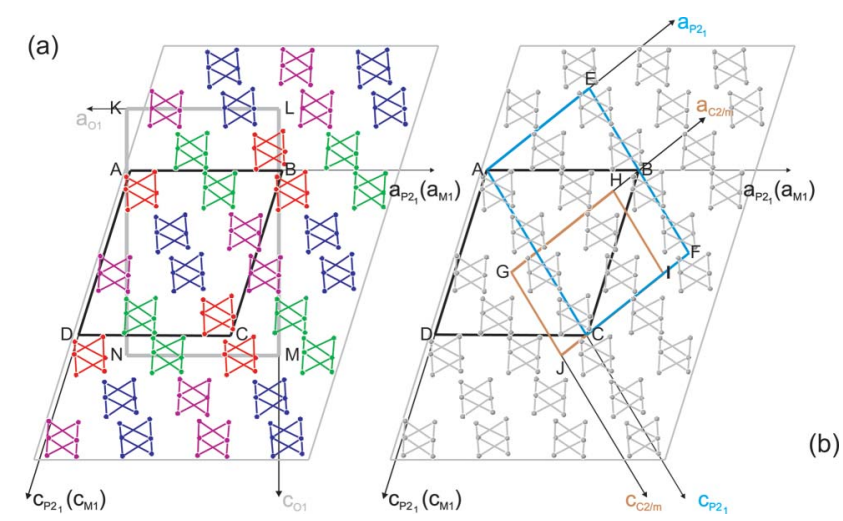

Fig. 4 Projection along the 010 direction (ac-plane) of the Bi-atoms of the eight complex Bi-ions within a unit cell of the published monoclinic structure $\left(P 2_{1}\right)$ of $\left[\mathrm{Bi}_{6} \mathrm{O}_{4.5}(\mathrm{OH})_{3.5}\right]_{2}\left(\mathrm{NO}_{3}\right)_{11}{ }^{9}$ In (a), all the atoms of a complete $\mathrm{Bi}$-octahedra (Bi1, $\mathrm{Bi} 2, \mathrm{Bi} 3$ and $\mathrm{Bi} 4)$ within the large thin grey parallelogram are shown with their bonds in red, green, magenta and blue, respectively. In (b), the same atoms and bonds are shown in grey for simplicity. In (a), a related orthorhombic cell $\mathrm{O} 1$ is marked by the thick grey rectangle KLMN. Two other related monoclinic cells are indicated by the rhomb's AEFC (blue) and GHIJ (brown) in (b). Within the original $P 2_{1}$-coordinate system (M1), the origins of the orthorhombic $\mathrm{O} 1$ and monoclinic $P 2_{1}$ (blue) and $C 2 / m$ (brown) cells are (29/32 $\left.0-3 / 8\right),(00$ $0)$ and $(3 / 81 / 45 / 8)$, respectively. For further details see the text and Table 4.

3.2.2. The published structure model with stacking faults of the complex Bi-ions. The crystals prepared for the structure investigation of $\left[\mathrm{Bi}_{6} \mathrm{O}_{4}(\mathrm{OH})_{4}\right]\left(\mathrm{NO}_{3}\right)_{6}{ }^{10}$ were obtained in a rapid growth mode, where drops of an acid bismuth nitrate solution were dropped into a 50:50 ethanol water solution. This resulted in a rapid dilution and precipitation of crystals where the two complex ions were packed in the crystals in a disordered way. Similarly, the crystals of samples from bath- $\mathbf{X}^{7}$ were also made in a process of very fast crystal growth. Here, the hydrolysis of urea to ammonia and carbon dioxide pulled the equilibrium of the ions from $\left[\mathrm{Bi}_{6} \mathrm{O}_{4}(\mathrm{OH})_{4}\right]^{6+}$ towards $\left[\mathrm{Bi}_{6} \mathrm{O}_{5}(\mathrm{OH})_{3}\right]^{5+}$, a process also observed in the in situ experiment. ${ }^{8}$ As argued in section 1 , it is more likely that batch-X material does not contain a 
Table 4 Relevant data for the original and additional unit cell choices associated with this work ${ }^{a}$ and ref. 9 and $10^{b}$

\begin{tabular}{|c|c|c|c|c|c|c|c|}
\hline Space group & $P 2_{1}(\mathrm{M} 1)$ monoclinic & O1 orthorhombic & $P 2_{1}$ monoclinic & $C 2 / m$ monoclinic & $R \overline{3}$ trigonal & $\mathrm{O} 2$ orthorhombic ${ }^{d}$ & $P 2_{1}(\mathrm{M} 2)$ monoclinic \\
\hline \multirow{2}{*}{$\begin{array}{l}a c \text {-plane projection } \\
\text { Ref. }\end{array}$} & $\mathrm{ABCD}$ & KLMN & AEFC & GHIJ & OPQR & STUV & XYZW \\
\hline & this work & this work & this work & this work & this work & this work & this work \\
\hline \multirow{3}{*}{$\begin{array}{l}\text { Fig. } \\
a / \AA\end{array}$} & $4 a$ and $4 b$ & $4 a$ & $4 b$ & $4 b$ & $5 b$ & $5 \mathrm{a}$ & $5 \mathrm{a}$ and $5 \mathrm{~b}$ \\
\hline & 15.8404 & 15.8404 & 13.7154 & 13.7161 & 15.1865 & 15.8416 & 15.8416 \\
\hline & 15.850 & 15.850 & 13.7449 & 13.7449 & 15.1332 & 15.7909 & 15.7909 \\
\hline$b / \AA ̊$ & 15.1982 & 15.1982 & 15.1928 & 15.1943 & 15.1865 & 15.18650 & 15.18650 \\
\hline & 18.230 & 26.1038 & 20.2836 & 10.1418 & 15.7909 & 26.2115 & 18.2499 \\
\hline \multirow[t]{2}{*}{$\beta$} & $106.829^{\circ}$ & $90^{\circ}$ & $98.502^{\circ}$ & $98.66^{\circ}$ & $120^{\circ}$ & $90^{\circ}$ & $106.759^{\circ}$ \\
\hline & $107.329^{\circ}$ & & $98.36^{\circ}$ & $98.36^{\circ}$ & & & $106.763^{\circ}$ \\
\hline \multirow{2}{*}{ Volume $/ \AA^{3}$} & 4219.8 & 6329.7 & 4218.5 & 2110.1 & 3164.1 & 6328.1 & 4218.8 \\
\hline & 4133.6 & 6200.4 & 4133.6 & 2066.8 & 3131.8 & 6263.7 & 4175.2 \\
\hline
\end{tabular}

${ }^{a}$ The parameters listed in bold are the results of the Le Baille profile matching analyses of pattern 1 (X-rays) and pattern 2 (neutrons). ${ }^{b}$ The parameters listed in italics are calculated from the unit cells for $P 2_{1}{ }^{9}$ (columns 2-5) and $R \overline{3}^{10}$ (columns 6 to 8 ). ${ }^{c}$ The parameters for the orthorhombic cell (O1) have been calculated from the monoclinic $P 2_{1}(\mathrm{M} 1)$ cell. ${ }^{d}$ The parameters for the orthorhombic cell $(\mathrm{O} 2)$ and monoclinic cell (M2) have been calculated from the trigonal $R \overline{3}$ cell.

Table 5 Refined Bi atom positions for space group $C 2 / m, a=13.7161(1)$ $b=15.1943(1), c=10.2399(1) \AA, \beta=98.586(1)^{\circ}$

\begin{tabular}{llllll}
\hline Atom & $x / a$ & $y / b$ & $z / c$ & $B\left(\AA^{2}\right)$ & Occupancy \\
\hline Bi1 & $0.163(1)$ & $0.137(2)$ & $0.151(2$ & 1.0 & 1.0 \\
Bi2 & $0.416(1)$ & $0.066(2)$ & $0.209(2)$ & 1.0 & 1.0 \\
Bi3 & $0.268(2)$ & $0.081(2)$ & $0.475(2)$ & 1.0 & 1.0 \\
Bi4 & $0.211(2)$ & $-0.078(2)$ & $0.012(2)$ & 1.0 & 1.0 \\
Bi5 & $0.321(1)$ & $-0.136(2)$ & $0.334(2)$ & 1.0 & 1.0 \\
Bi6 & $0.061(1)$ & $-0.055(2)$ & $0.261(2)$ & 1.0 & 1.0 \\
\hline
\end{tabular}

water molecule. The composition could then be described by the formula: $\left[\mathrm{Bi}_{6} \mathrm{O}_{4}(\mathrm{OH})_{4}\right]_{0.5+x}\left[\mathrm{Bi}_{6} \mathrm{O}_{5}(\mathrm{OH})_{3}\right]_{0.5-x}\left(\mathrm{NO}_{3}\right)_{5.5+x}$ with $x=0.0$, and the ratio between the two complex ions would be $1: 1$, in agreement with chemical $\mathrm{Bi}$ and $\mathrm{NO}_{3}{ }^{-}$analyses, ${ }^{8}$ or in other words, the chemical composition of batch-X samples is the same as the chemical composition of the material investigated by Henry et al. in $2003{ }^{9}$

However, as mentioned in section 1, the X-ray diffraction pattern calculated from the published structure of Henry et al. in $2006^{10}$ is almost identical with the present powder pattern 1 (Fig. 1). Therefore, it must be assumed that the chemical composition for the $R \overline{3}$ structure determined by Henry et al. in $2006^{10}$ is the same as that found in their former investigation. ${ }^{9}$ Because the four different Bi-complexes of that structure ${ }^{10}$ overlap, this further implies that the $R \overline{3}$ is a disordered structure with composition $\left[\mathrm{Bi}_{6} \mathrm{O}_{4}(\mathrm{OH})_{4}\right]_{0.5+x}\left[\mathrm{Bi}_{6} \mathrm{O}_{5}(\mathrm{OH})_{3}\right]_{0.5-x}\left(\mathrm{NO}_{3}\right)_{5.5+x}$, where the ratio between the two Bi-complexes need not be $1: 1$. In section 4.3, the present neutron powder diffraction data of batch-X material (pattern 2, Fig. 2 and 6) is analysed in terms of this assumption.

\section{Refinement of the batch-X diffraction data}

\subsection{Space group and model refinements of possible crystal structures of powder pattern 1}

When using FullProf ${ }^{15}$ in a Le Bail type profile match calculation, pattern 1 can be matched with four different unit cells as listed below (Case-A, -B, -C and D). Within the accuracy of the data,
Table 6 Atom coordinates $(R \overline{3}, a=b=15.1865(1) \AA$ and $c=$ $15.8416(1) \AA), B O V=0$. The $R$ factors are: $R_{\mathrm{Bragg}}=16.9 \%, R_{\mathrm{F}}=15.4 \%$ and $\chi^{2}=2.5$

\begin{tabular}{llllll}
\hline Atoms & $x$ & $y$ & $z$ & $B_{\text {iso }}\left(\AA^{2}\right)$ & Occupancy \\
\hline Bi1a & $-0.1284(7)$ & $0.0134(5)$ & $0.1432(5)$ & $3.6(1)$ & $0.54(1)$ \\
Bi1b & $0.1382(7)$ & $-0.0112(5)$ & $0.3450(5)$ & $3.6(1)$ & $0.54(1)$ \\
Bi2a & $0.1423(8)$ & $0.0038(5)$ & $0.1418(5)$ & $3.6(1)$ & $0.46(1)$ \\
Bi2b & $-0.1497(8)$ & $-0.0179(5)$ & $0.3539(5)$ & $3.6(1)$ & $0.46(1)$ \\
O1 & 0.00000 & 0.00000 & $0.3860(6)$ & $4.4(1)$ & 0.167 \\
O2 & 0.00000 & 0.00000 & $0.0963(6)$ & $4.4(1)$ & 0.167 \\
O11 & $0.1455(6)$ & $-0.0152(7)$ & $0.1959(5)$ & $4.4(1)$ & $0.54(1)$ \\
O12 & $-0.1435(6)$ & $0.0114(7)$ & $0.2938(5)$ & $4.4(1)$ & $0.54(1)$ \\
O21 & $-0.1452(7)$ & $-0.0042(7)$ & $0.2045(5)$ & $4.4(1)$ & $0.46(1)$ \\
O22 & $0.1529(6)$ & $0.0180(7)$ & $0.2926(5)$ & $4.4(1)$ & $0.46(1)$ \\
N3 & $0.0525(6)$ & $0.5318(8)$ & $0.1638(4)$ & $4.4(1)$ & $0.830(9)$ \\
O31 & $0.008(1)$ & $0.511(2)$ & $0.0950(7)$ & $4.4(1)$ & $0.830(9)$ \\
O32 & $-0.005(1)$ & $0.481(1)$ & $0.2222(8)$ & $4.4(1)$ & $0.830(9)$ \\
O33 & $0.132(1)$ & $0.6169(9)$ & $0.165(2)$ & $4.4(1)$ & $0.830(9)$ \\
N4 & $-0.0341(7)$ & $0.2483(7)$ & $0.0827(5)$ & $4.4(1)$ & $0.479(9)$ \\
O41 & $-0.019(1)$ & $0.298(1)$ & $0.0160(7)$ & $4.4(1)$ & $0.479(9)$ \\
O42 & $-0.045(3)$ & $0.192(2)$ & $0.022(2)$ & $4.4(1)$ & $0.479(9)$ \\
O43 & $-0.1271(9)$ & $0.192(2)$ & $0.095(2)$ & $4.4(1)$ & $0.479(9)$ \\
N5 & $0.034(1)$ & $0.2733(9)$ & $-0.0277(9)$ & $4.4(1)$ & $0.521(9)$ \\
O51 & $-0.019(1)$ & $0.298(1)$ & $0.0160(7)$ & $4.4(1)$ & $0.521(9)$ \\
O52 & $0.017(3)$ & $0.184(1)$ & $-0.019(3)$ & $4.4(1)$ & $0.521(9)$ \\
O53 & $0.068(2)$ & $0.329(3)$ & $-0.092(2)$ & $4.4(1)$ & $0.521(9)$ \\
H1 & 0.00000 & 0.00000 & $0.4490(6)$ & $4.4(1)$ & 0.083 \\
H2 & 0.00000 & 0.00000 & $0.0332(6)$ & $4.4(1)$ & 0.083 \\
H11 & $0.205(1)$ & $-0.019(2)$ & $0.174(1)$ & $4.4(1)$ & $0.27(1)$ \\
H12 & $-0.204(1)$ & $0.018(2)$ & $0.310(1)$ & $4.4(1)$ & $0.27(1)$ \\
H21 & $-0.209(1)$ & $-0.005(2)$ & $0.186(1)$ & $4.4(1)$ & $0.23(1)$ \\
H22 & $0.221(1)$ & $0.027(2)$ & $0.311(1)$ & $4.4(1)$ & $0.23(1)$ \\
\hline & & & & &
\end{tabular}

the zero offset for pattern 1 was found to be small and therefore was kept fixed at zero during refinement. The half width parameters $U, V, W$ and $Y$ were determined by profile refinement using only the $R \overline{3}$ space group (Case-A) and fixed to these values when refining the pattern in the other space groups (Case-B, -C and -D). This procedure was adopted in order to limit the number of matched profiles to a realistic number. The resulting half width parameters are quoted in the caption to Fig. 1 and were used in the subsequent structure refinements of pattern 1 using the ordered and disordered $\mathrm{Bi}_{6}$-ion octahedra. All profile matching and model 
structure refinements mentioned in the following were continued until convergence was reached.

Case-A. A trigonal space group $R \overline{3}$ with hexagonal setting, $a=$ 15.18650(6), $c=15.8416(1) \AA, V=3164.1 \AA^{3}$ with $R_{\text {Bragg }}=0.12 \%$, $R_{\mathrm{F}}=0.25 \%$ and $\chi^{2}=2.9$ (Fig. 1). This cell corresponds to lattice parameters of the published structure of $\left[\mathrm{Bi}_{6} \mathrm{O}_{4}(\mathrm{OH})_{4}\right]\left(\mathrm{NO}_{3}\right)_{6}{ }^{10}$ (see Table 1). Using pattern 1 and $R \overline{3}$ in conjunction with the $a b$ initio structure solving program $\mathrm{FOX}^{16}$ confirms that the structure of sample- $\mathbf{X}$ has indeed a disordered arrangement of the two types of complex Bi-ions, $\left[\mathrm{Bi}_{6} \mathrm{O}_{4}(\mathrm{OH})_{4}\right]^{6+}$ and $\left[\mathrm{Bi}_{6} \mathrm{O}_{5}(\mathrm{OH})_{3}\right]^{5+}$. The structure model $^{10}$ has four Bi-ion sites each with approximate occupancy $\frac{1}{2}$. Thus, in hexagonal setting, its trigonal $R \overline{3}$ unit cell has a total of $18 \mathrm{Bi}$-ion sites $(18 f)$ of the average composition or rather a mixture of 18 ions $\left[\mathrm{Bi}_{6} \mathrm{O}_{4}(\mathrm{OH})_{4}\right]^{6+}$ and $\left[\mathrm{Bi}_{6} \mathrm{O}_{5}(\mathrm{OH})_{3}\right]^{5+}$. This is in reasonable agreement with the average composition $\left[\mathrm{Bi}_{6} \mathrm{O}_{4.5}(\mathrm{OH})_{3.5}\right]^{5.5+}$ of a batch-X sample found in the chemical analysis. ${ }^{8}$ A model calculation using pattern 1 and scattering contribution from only the four Bi-atoms on the $18 f$ sites resulted in $R_{\text {Bragg }}=26.5 \%, R_{\mathrm{F}}=18.3 \%$ and $\chi^{2}=9.5$.

Case-B1. A monoclinic space group $P 2_{1}, a=15.8404(1), b=$ 15.1982(1), $c=18.3122(1) \AA, \beta=106.829(1)^{\circ}, V=4219.8 \AA^{3}$ with $R_{\text {Bragg }}=0.33 \%, R_{\mathrm{F}}=0.35 \%$ and $\chi^{2}=1.5$. This unit cell does indeed match the cell of the published structure of $\left[\mathrm{Bi}_{6} \mathrm{O}_{4.5}(\mathrm{OH})_{3.5}\right]_{2}\left(\mathrm{NO}_{3}\right)_{11},{ }^{9}$ but has slightly different dimensions. It corresponds to the $P 2_{1}$ cell projected as in the parallelogram $\mathrm{ABCD}$ in Fig. 4. Using the program FullProf ${ }^{15}$ and pattern 1 in a structure refinement with the refined $P 2_{1}$ unit cell and the published structure model ${ }^{9}$ with scattering contributions from only the $24 \mathrm{Bi}$ atoms resulted in a very bad fit with $R_{\text {Bragg }}=65.4 \%$, $R_{\mathrm{F}}=52.7 \%$ and $\chi^{2}=21.1$. This is a surprisingly poor fit because the Bi-atoms give the major contribution to the X-ray scattering and the missing scattering contributions from the $\mathrm{O}$ - and $\mathrm{N}$-atoms can not account for the discrepancy.

Case-B2. Close inspection of the packing of the $\mathrm{Bi}_{6}$ octahedra in the $P 2_{1}$ structure of $\left[\mathrm{Bi}_{6} \mathrm{O}_{4.5}(\mathrm{OH})_{3.5}\right]_{2}\left(\mathrm{NO}_{3}\right)_{11}{ }^{9}$ suggests a disordered modification of this model. Fig. 4 reveals that the $\mathrm{Bi}_{6}$ octahedra have centre's lying close to planes parallel to the $\boldsymbol{a c}$ planes at $y=1 / 4$ and $y=\frac{3}{4}$. In addition, the figure also shows that the $\mathrm{Bi}_{6}$-octahedra with $z$-coordinates between 0 and $\frac{1}{2}$ have almost the same relative positions to each other as the $\mathrm{Bi}_{6}$-octahedra with $z$ coordinates between $\frac{1}{2}$ and 1 . If an additional set of $24 \mathrm{Bi}$ atoms is introduced in the present model calculation with the coordinates $x$, $y, z+\frac{1}{2}$, derived from the $x, y, z$ coordinates of the first $24 \mathrm{Bi}$ atoms, this corresponds to a disordered arrangement of the $\mathrm{Bi}_{6}$ octahedra of the model. This model calculation resulted in a significant improvement of the fit with $R_{\text {Bragg }}=32.7 \%, R_{\mathrm{F}}=30.5 \%$ and $\chi^{2}=$ 8.2 , indicating that the data of pattern 1 may be modelled better in this $P 2_{1}$ monoclinic unit cell with a disordered arrangement of two sets of $24 \mathrm{Bi}$ octahedra where the atoms in each set has occupancy $\frac{1}{2}$ than with an ordered arrangement of Bi octahedra.

Case-C. A monoclinic space group $P 2_{1}, a=13.7154(2), b=$ $15.1928(1), c=20.4696(5) \AA, \beta=98.502(1)^{\circ}$ and $V=4218.5 .0 \AA^{3}$ with $R_{\text {Bragg }}=0.21 \%, R_{\mathrm{F}}=0.31 \%$ and $\chi^{2}=1.6$. This cell was derived from the DICVOL $04^{13}$ solution of pattern 1 by doubling the $\boldsymbol{a}$ - and $c$-axes. It corresponds to the $P 2_{1}$ cell projected as the parallelogram AEFC in Fig. 4b and resembles the cell found in the single crystal measurements (pattern 5) if the $c$-axis of that cell is doubled (see
Table 3). The two cells determined for Case-B and Case-C are related and have the same volume. Hence, the packing of the $\mathrm{Bi}_{6}$-octahedra in the AEFC $P 2_{1}$ cell can easily be derived from the packing of the $\mathrm{Bi}_{6}$-octahedra in the $\mathrm{ABCD} P 2_{1}$ structure. ${ }^{9}$ Refinements of the positions of the transformed atoms (Case-B2) in the $\mathrm{Bi}_{6}$-octahedra of the Case-C cell give $R_{\text {Bragg }}=26.6 \%, R_{\mathrm{F}}=$ $25.9 \%$ and $\chi^{2}=7.9$. A similar calculation made using pattern 3 (Fig. 3b) showed that in both cases the best model could be obtained if the $\mathrm{Bi}_{6}$-octahedra were patched into each other as in Case-B2.

Case-D. A monoclinic space group $C 2 / m$ gives $a=13.7161(1)$, $b=15.1943(1), c=10.2399(1) \AA, \beta=98.586(1)^{\circ}$ and $V=2110.1 \AA^{3}$ with $R_{\text {Bragg }}=0.13 \%, R_{\mathrm{F}}=0.19 \%$ and $\chi^{2}=2.6$ with pattern 1 and the Le Baille type profile match fitting. The single crystal measurements made on the NSLS diffractometer at beam line X7B gave a $C 2 / m$ unit cell with $a=13.716(3), b=15.176(3), c=$ 10.225(3) $\AA, \beta=98.60(3)^{\circ}$ and $V=2104.4 \AA^{3}$. A structure solution using the direct method pack SHELXTL ${ }^{17}$ gave $\mathrm{Bi}_{6}$-octahedra patched into each other. The mirror plane of the $C 2 / \mathrm{m}$ space group generates a solution with octahedra centres at $y=0$ and $y=\frac{1}{2}$. This obviously corresponds to a too high symmetry, and the model does not account for the two different types of ions in the structure, $\left[\mathrm{Bi}_{6} \mathrm{O}_{4}(\mathrm{OH})_{4}\right]^{6+}$ and $\left[\mathrm{Bi}_{6} \mathrm{O}_{5}(\mathrm{OH})_{3}\right]^{5+}$. The model has eight octahedra and six $\mathrm{Bi}$ site positions corresponding to 48 Bi-atoms or equivalently, four $\left(\mathrm{Bi}_{6}\right)_{0.5}\left(\mathrm{Bi}_{6}\right)_{0.5}$ clusters in the unit cell. The positions of the clusters in the unit cell correspond to the positions of the Bi-atoms in the $\boldsymbol{a c}$ - cell projection GHIJ with the axes $\boldsymbol{a}_{C 2 / m}$ and $\boldsymbol{c}_{C 2 / m}$ as displayed in Fig. 4b. With scattering contributions from only the six Bi-atoms in a refinement using FullProf ${ }^{15}$ and pattern 1 this model results in $R_{\text {Bragg }}=23.7 \%, R_{\mathrm{F}}=$ $21.1 \%$, and $\chi^{2}=7.2$. The Bi-coordinates of this refinement are listed in Table 5 .

In summary, the reliability factors $R_{\mathrm{F}}$ found for the FullProf refinements of the X-ray diffraction data in pattern 1 when considering the arrangements of disordered $\mathrm{Bi}_{6}$-octahedra in four different space groups are: $18.3 \%, 52.7 \%, 30.5 \%, 25.9 \%$ and $21.1 \%$ for Case-A, -B1, -B2, -C and -D, respectively.

\subsection{Relationship between the structure models described in the $P 2_{1}{ }^{9}$ and $\boldsymbol{R} \overline{\mathbf{3}}^{10}$ space groups}

In section 3.2.2. it was concluded that the model structures found by Henry et al. ${ }^{9,10}$ had to be related, although originally described in two different space groups. Before testing the validity of this conclusion on the present batch-X material the geometrical arrangement of the Bi-atoms in the two models are examined in detail and compared to the unit cell parameters listed in Tables $1-4$.

Fig. 4 displays a projection along the 010 direction of the $\mathrm{Bi}$ atoms in the monoclinic $P 2_{1}$ model structure9 (called M1 below). It illustrates how the different Bi-atoms of the eight complex Bi-ions are placed. The atoms within the black parallelogram $\mathrm{ABCD}$ shows the original unit cell projection with volume $V=$ $4133.7 \AA^{3}\left(a_{P 2_{1}}=15.850(3), b_{P 2_{1}}=14.986(3), c_{P 2_{1}}=18.230(4) \AA\right.$, $\left.\beta_{\mathrm{M}}=107.329(17)^{\circ}\right) .^{9}$ The projections on the ac-plane of three other parallelepipeds, which represent possible unit cells for $\left[\mathrm{Bi}_{6} \mathrm{O}_{4.5}(\mathrm{OH})_{3.5}\right]_{2}\left(\mathrm{NO}_{3}\right)_{11}$, are also indicated. They are the grey rectangle KLMN in Fig. 4a (orthorhombic O1) and in Fig. 4b, the light blue parallelogram AEFC (monoclinic $P 2_{1}$ ) and the brown 
parallelogram GHIJ (monoclinic $C 2 / m$ ). The volumes of these cells are either the same (AEFC) or half (GIHJ) that of the original monoclinic cell. The lattice parameters and volumes calculated from the original cell ${ }^{9} \mathrm{M} 1$ are listed in italics in columns 2 to 5 in Table 4 and can be compared to the corresponding values in bold calculated from the data in Table 3. An obvious analogy to the unit cells listed in Table 3 is easily recognized.

The test refinement made in section 3.3.1. with pattern 1 and the $R \overline{3}$ unit cell using only scattering contributions from the Bi atoms gave $R_{\mathrm{F}}=18.3 \%$, which is comparable to the above mentioned result (21.1\%) obtained for the $C 2 / m$ (case-D) monoclinic cell. ${ }^{9}$ The volume of the $R \overline{3}$ cell is $3164.1 \AA^{3}$, or about $50 \%$ larger than the volume of the monoclinic $C 2 / m$ cell $\left(V=2110.1 \AA^{3}\right)$. The volumes of the cells used in Case-B1 (-B2) and -C are $4219.8 \AA^{3}$ and $4218.5 .0 \AA^{3}$, which is at least $100 \%$ larger than the volumes of the other monoclinic cells listed in Table 3.

Fig. 5 displays a simplification of the $R \overline{3}$ model structure ${ }^{10}(a$, $c=a_{\mathrm{T}}, c_{\mathrm{T}}$ ) with only one pair of $\mathrm{Bi}_{6}$-octahedra (Bila and Bilb atom sites). Fig. 5a and $5 \mathrm{~b}$ show the projections along the 110and 001-directions (OPQR in yellow), respectively. Two other unit cells are also displayed. The first is an orthorhombic cell $(\mathrm{O} 2$, orange) marked STUV in 5a and STÆØ in 5b. It is chosen with $a_{\mathrm{O} 2}=a_{\mathrm{T}}, b_{\mathrm{O} 2}=2 \cdot a_{\mathrm{T}} \cdot \cos \left(30^{\circ}\right)$ and $c_{\mathrm{O} 2}=c_{\mathrm{T}}$ and has a cell volume of $6263.7 \AA^{3} \cdot{ }^{10}$ The other is a $P 2{ }_{1}$ monoclinic cell (M2) with a volume two thirds that of the orthorhombic cell O2. It is shown as the parallelepiped XYZW (light green) in Fig. 5a. The unit cell parameters and volumes for the case-A trigonal structure (Table 3) and the derived $\mathrm{O} 2$ and $\mathrm{M} 2$ structures are listed in columns 6 to 8 of Table 4. For comparison, the corresponding cell values calculated from the model structure ${ }^{10}$ are listed in italics in the same columns. The analogies to the unit cells listed in Table 3
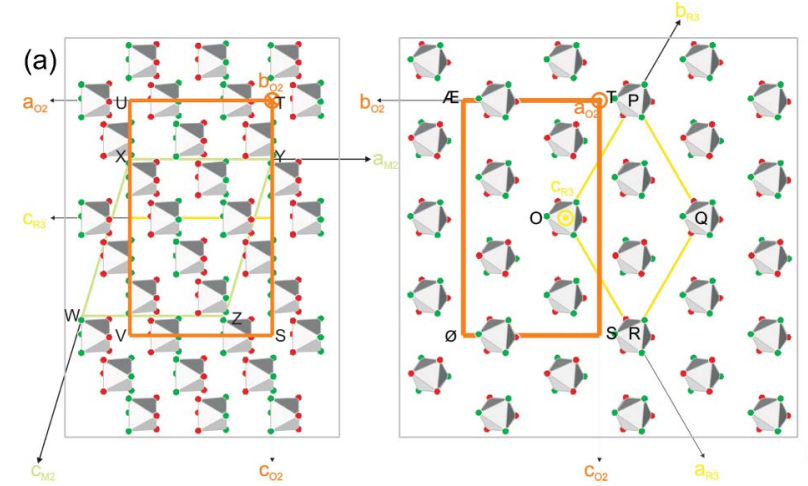

Fig. 5 Projections of the Bila (red) and Bilb (green) atoms in the published trigonal structure $R \overline{3}$ (hexagonal setting) of $\left[\mathrm{Bi}_{6} \mathrm{O}_{4}(\mathrm{OH})_{4}\right]\left(\mathrm{NO}_{3}\right)_{6} \cdot{ }^{10}$ Only the atoms of complete Bi-octahedra within the large thin grey rectangles are shown. (a) The projection perpendicular to the hexagonal plane and (b) the corresponding projection on the hexagonal plane. The rhomb OPQR (yellow) in (b) marks the $\boldsymbol{a b}$-plane projection of the $R \overline{3}$ unit cell with volume $V=3131.8 \AA^{3}$. The related rectangles STUV and STÆØ (orange) in (a) and (b) are the projections of an orthorhombic cell O2 with twice the volume of the original $R \overline{3}$ cell $\left(6263.7 \AA^{3}\right)$. In (a), the light green parallelogram XYZW marks the projections of a monoclinic cell M2 which is equivalent to the original $P 2_{1}$ cell shown in Fig. 4 (black). Within the original $R \overline{3}$-coordinate system, the origins of the orthorhombic $\mathrm{O} 2$ and monoclinic M2 cells have coordinates (-1/4 3/4 0) and (0 1/2 0) and projected as the points marked $\mathrm{T}$ and $\mathrm{X}$, respectively. For further details see the text and Table 4 . and the unit cells calculated for the monoclinic unit cell of Ref. 9 (columns 2 to 5) are easily recognized.

Hence, the packing of Bi-atoms displayed in Fig. 4 and Fig. 5 shows a great similarity with respect to the packing of the $\mathrm{Bi}_{6}$ octahedra and from a purely packing point of view it may be argued that the two structures, the monoclinic $P 2_{1}$ and the trigonal $R \overline{3}$ structures, are related. However, the $\mathrm{Bi}_{6}$ octahedra in the two structure models have different symmetries defined by the symmetry of the two space groups. The $P 2_{1}$ structure has twentyfour different $\mathrm{Bi}$ atom site positions. Twelve of these $\mathrm{Bi}$ atoms form two of the complex ions $\left[\mathrm{Bi}_{6} \mathrm{O}_{4}(\mathrm{OH})_{4}\right]^{6+}$, and the remaining twelve $\mathrm{Bi}$ atoms form two of the complex ions $\left[\mathrm{Bi}_{6} \mathrm{O}_{5}(\mathrm{OH})_{3}\right]^{5+}$. This is illustrated by the red, green, blue and violet octahedra in Fig. 4a. It is important to note that there are neither symmetry relations between the Bi-atom positions within a given octahedron or within the four independent octahedra. The $P 2_{1}$ structure has an ordered packing of these two types of complex ions illustrated by the hydrogen bonds between the complexes. ${ }^{9}$

The trigonal $R \overline{3}$ structure $^{10}$ has two different $\mathrm{Bi}$ atom site positions Bila and $\mathrm{Bilb}$ and each $\mathrm{Bi}_{6}$ octahedron is formed by three symmetry related $\mathrm{Bi}$ atoms of type Bila and three symmetry related $\mathrm{Bi}$ atoms of type $\mathrm{Bil} \mathrm{b}$, forming the complex ion $\left[\mathrm{Bi}_{6} \mathrm{O}_{4}(\mathrm{OH})_{4}\right]^{6+}$, or the complex ion $\left[\mathrm{Bi}_{6} \mathrm{O}_{5}(\mathrm{OH})_{3}\right]^{5+}$, illustrated by the red and green $\mathrm{Bi}$ atoms in Fig. 5. Stacking faults can be introduced in this structure via two additional $\mathrm{Bi}$ atom site positions $\mathrm{Bi} 2 \mathrm{a}$ and $\mathrm{Bi} 2 \mathrm{~b}$, forming the same type of complex ions $\left[\mathrm{Bi}_{6} \mathrm{O}_{4}(\mathrm{OH})_{4}\right]^{6+}$ and $\left[\mathrm{Bi}_{6} \mathrm{O}_{5}(\mathrm{OH})_{3}\right]^{5+}$, and this is the only way the $R \overline{3}$ structure can be realized as an acceptable structure model for the pattern $1 \mathrm{X}$-ray data.

Introducing stacking faults in the $P 2_{1}$ structure model in Fig. 4 , as was done in the model calculation case- $\mathrm{B} 2$, illustrates that the pattern 1 data can possibly be modelled in the $P 2_{1}$ space group. It is thus possible that the correct unit cell and space group for the sample batch-X would be $a=15.8404(2), b=15.1982(1), c=$ 18.3122(1) $\AA, \beta=106.829(1)^{\circ}, V=4219.8 \AA^{3}$, see Table 3. Although it was identified for the twinned crystal of Henry et al., ${ }^{9}$ this larger unit cell was neither observed in the present indexing of pattern 1 , nor in the measurements of the two sets of single crystal X-ray data. It was only identified via systematic tests of possible space groups using FullProf and thus clearly illustrates the problems mentioned above in handling X-ray data for heavy atom structures. To truly confirm the existence of this large monoclinic cell, better single crystal data would be necessary because the available single crystal data sets collected within the smaller unit cells $3160.2 \AA^{3}$ and $2104.4 \AA^{3}$ can not be transformed to complete data sets for the larger unit cells and corresponding space groups.

\subsection{Structure model determined from powder neutron diffraction data}

As mentioned above, a detailed structure analysis using the available X-ray and neutron powder patterns can only give average structures. However, within the accuracy of the present data, the large $P 2_{1}$ monoclinic cell ${ }^{9}$ has too many adjustable atomic parameters and the smaller monoclinic cell model using the space group $C 2 / m$ (Table 5) can not distinguish between the two complex $\mathrm{Bi}_{6}$-ions because of the higher space group symmetry. Therefore, a structure analysis was made in the space group $R \overline{3}$ using only the neutron powder diffraction pattern, which gives more accurate 

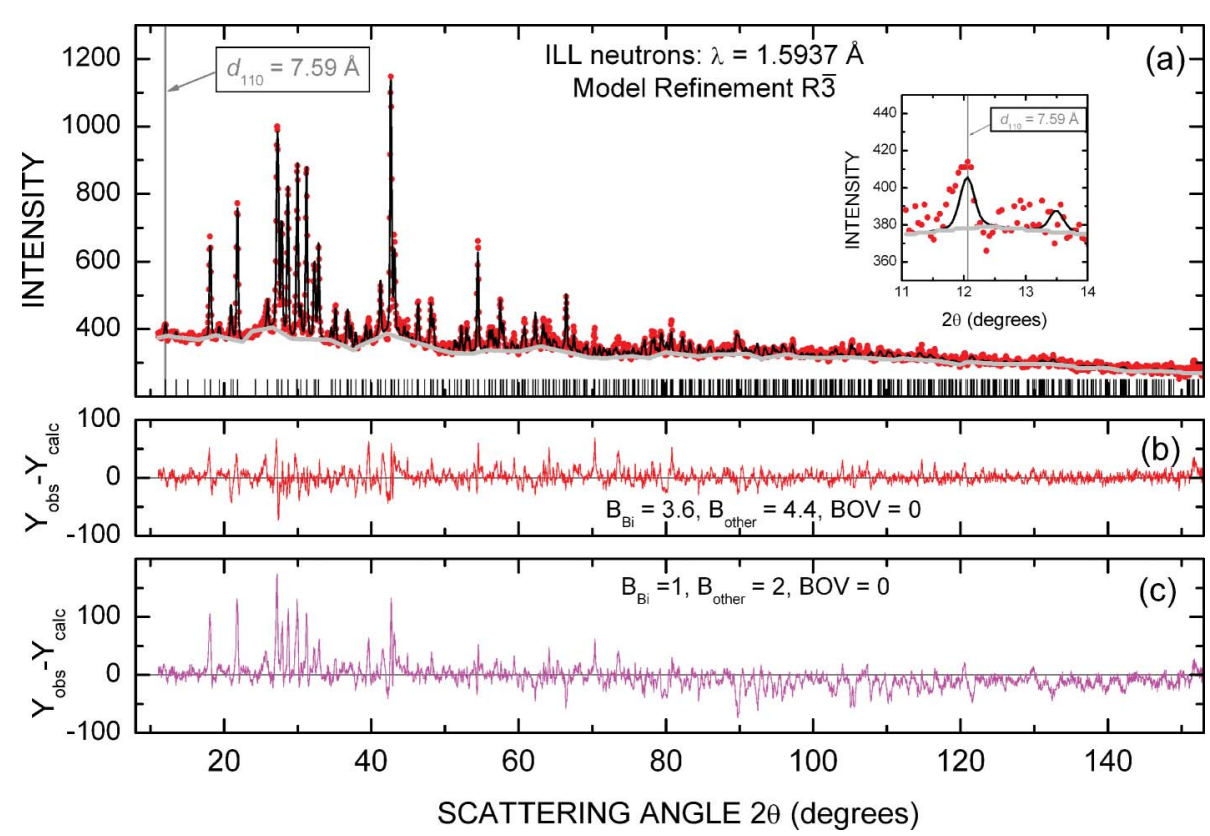

Fig. 6 Neutron powder diffraction pattern of a batch-X sample recorded at $25^{\circ} \mathrm{C}$. (a) The results of the final refinement ((๑) observed and ( - c) calculated). Details of the lowest angle peak observed in this pattern are shown in the inset (d). The vertical ticks mark the Bragg peak positions. The calculated pattern is obtained by refinement using the FullProf ${ }^{15}$ program and an initial structure model based on the $R \overline{3}$ structure model of Henry et al. ${ }^{10}$ Details about the refinement procedure are given in section 4.3. and the refined parameters are listed in Table 6. (b) The difference pattern (red curve) between the observed and calculated patterns in (a) using refined isotropic temperature factors $B_{\mathrm{Bi}}=3.6$ and $B_{\text {other }}=4.4$ and $B O V=0$. (c) The difference pattern (magenta curve) obtained when using fixed isotropic temperature factors $B_{\mathrm{Bi}}=1$ and $B_{\text {other }}=2$ and $B O V=0$. The fat grey curve in (a) and (d) shows the background.

site coordinates and compositions than the corresponding X-ray data. Furthermore, the $R \overline{3}$ cell can, at least in principle, distinguish between the two complex $\mathrm{Bi}_{6}$-ions.

The model calculation was made using the refinement mode of the program FullProf ${ }^{15}$ and pattern 2 . The results of the refinement are shown in Fig. 6. The start model used in the calculations was based on the published structure $R \overline{3}$ of $\left[\mathrm{Bi}_{6} \mathrm{O}_{4}(\mathrm{OH})_{4}\right]\left(\mathrm{NO}_{3}\right)_{6}{ }^{10}$ with the $\mathrm{H}$-atom positions obtained from packing considerations. In the refinements the following distance constraints were applied: $\mathrm{Bi}-$ $\mathrm{O}=2.38 \AA, \mathrm{Bi}-\mathrm{OH}=2.3 \AA, \mathrm{Bi}-\mathrm{H}=2.9 \AA, \mathrm{O}-\mathrm{H}=1 \AA$ and $\mathrm{N}-\mathrm{O}=$ $1.25 \AA$. The lattice parameters, zero offset and profile parameters were those obtained in the Le Bail profile fitting and quoted in the caption of Fig. 2. The background was initially described by 50 points determined by FullProf and manually adjusted as the refinement progressed. The final background is shown as the grey curves in Fig. 6a and d. The positional parameters and occupancies were first refined for the two complex Bi ions, followed by positional parameters and occupancies for the nitrate ions. Attempts to include the refinement of isotropic temperature factors for the different atoms failed (no convergence, unrealistically large or negative $B$-factors). However, when using two different fixed isotropic $B$-factors, $B_{\mathrm{Bi}}=1.0 \AA^{2}$ and $B_{\text {other }}=2.0 \AA^{2}$, the refinement converged and a preliminary set of positional parameters and occupancies could be obtained. The difference pattern for this refinement with $R_{\text {Bragg }}=44.4 \%, R_{\mathrm{F}}=37.9 \%$ and $\chi^{2}=6.8$ is shown in Fig. 6c. Obviously this is not a good fit and the difference plot indicates clearly that the calculated intensity is underestimated at low angles and over estimated at high angles. In order to improve the model, the $B$-overall parameter $(B O V)$ in FullProf was allowed to vary and the refinement quickly converged for
$B O V=2.5$ with insignificant changes of the positional parameters and occupancies. A similar refinement of the X-ray data (pattern 1) using the same atom coordinates and occupancies, and allowing the scale factor and $B O V$ to vary, resulted in $R_{\text {Bragg }}=31 \%, R_{\mathrm{F}}=$ $24 \%$ and $\chi^{2}=9.1$ for $B O V=2.4(1) \AA^{2}$.

The $B O V$ was introduced as an additional parameter, which may hide the principal uncertainties in the assumed structural model as listed below:

(a) The disordered packing of the two Bi-complexes, which have almost the same composition.

(b) The disorder of the hydrogen atoms, because it was only possible to locate the $\mathrm{H}$-atoms at half of the $\mathrm{O}$-atoms. The remaining $\mathrm{H}$-atom positions were found by packing considerations, and the positions were fixed by constraining the distances.

(c) The use of the $R \overline{3}$ space group, while the space group of the structure is possibly monoclinic as discussed in section 4.2. Therefore, this model is an average model, and many of the parameters are strongly correlated, but the suggested model is the best achievable one with data available.

A final refinement was made with fixed $B O V=0$ and adjustable $B_{\mathrm{Bi}}$ and $B_{\text {other }}$, which resulted in $B_{\mathrm{Bi}}=3.6(1) \AA^{2}$ and $B_{\text {other }}=4.4(1) \AA^{2}$, which agrees well with the results for $B_{\text {iso }}+B O V$ found for the refinement above. The results of this final refinement with $R_{\text {Bragg }}=16.9 \%, R_{\mathrm{F}}=15.4 \%$ and $\chi^{2}=$ 2.5 is shown as the black calculated curve in Fig. 6a and the corresponding difference pattern in Fig. 6b. The atomic coordinates and occupancies are listed in Table 6 and the chemical composition of the sample derived from these results was found to be $\left[\mathrm{Bi}_{6} \mathrm{O}_{4}(\mathrm{OH})_{4}\right]_{0.54(1)}\left[\mathrm{Bi}_{6} \mathrm{O}_{5}(\mathrm{OH})_{3}\right]_{0.46(1)}\left(\mathrm{NO}_{3}\right)_{5.54(1)}$. The inter-atomic distances in the two complex ions are listed in Table 7. 
Table 7 Interatomic distances $(R \overline{3}, a=b=15.1865(1) \AA$ and $c=$ 15.8416(1) $\AA$ ). The complex molecules are formed by the atoms Bila, $\mathrm{Bilb}, \mathrm{O} 11, \mathrm{O} 12, \mathrm{O} 2, \mathrm{O} 1$ and $\mathrm{Bi} 2 \mathrm{a}, \mathrm{Bi} 2 \mathrm{~b}, \mathrm{O} 21, \mathrm{O} 22, \mathrm{O} 2, \mathrm{O} 1$, respectively

\begin{tabular}{llll}
\hline Atoms & Distance/A & Atoms & Distance/ \\
\hline Bi1a-O11 & $2.36(1)$ & N3-O31 & $1.24(2)$ \\
Bi1a-O12 & $2.40(1)$ & N3-O32 & $1.25(2)$ \\
Bi1a-O2 & $2.20(1)$ & N3-O33 & $1.25(1)$ \\
Bi1b-O11 & $2.37(1)$ & N4-O41 & $1.25(2)$ \\
Bi1b-O12 & $2.38(1)$ & N4-O42 & $1.25(2)$ \\
Bi1b-O1 & $2.29(1)$ & N4-O43 & $1.25(2)$ \\
Bi2a-O21 & $2.37(2)$ & N5-O51 & $1.24(3)$ \\
Bi2a-O22 & $2.40(1)$ & N5-O52 & $1.25(3)$ \\
Bi2a-O2 & $2.25(1)$ & N5-O53 & $1.26(3)$ \\
Bi2b-O21 & $2.38(1)$ & O1-H1 & $1.00(1)$ \\
Bi2b-O22 & $2.38(1)$ & O2-H2 & $1.00(1)$ \\
Bi2b-O1 & $2.20(1)$ & O11-H11 & $0.99(3)$ \\
& & O12-H12 & $1.00(2)$ \\
& & O21-H21 & $1.01(2)$ \\
& & O22-H22 & $1.01(2)$ \\
\hline
\end{tabular}

Fig. 7 shows a drawing of the two complex Bi-ions using the coordinates listed in Table 6 . In the model calculation it was not possible to distinguish between $\mathrm{O}$-atoms and $\mathrm{OH}$-groups on the surfaces of the two complex Bi-octahedra. The atoms Bila, $\mathrm{Bi} 1 \mathrm{~b}, \mathrm{O} 11$, and $\mathrm{O} 12$, plus $\mathrm{O} 1$ and $\mathrm{O} 2$ form one of the complex $\mathrm{Bi}$ molecules. The atoms Bi2a, Bi2b, O21, and $\mathrm{O} 22$, plus $\mathrm{O} 1$ and $\mathrm{O} 2$ form the other complex Bi molecule. The first of these ions has average $\mathrm{Bi}-\mathrm{Bi}$ distances of $3.66 \AA$, and must correspond to the ion with the largest number of $\mathrm{OH}$-groups, which is $\left[\mathrm{Bi}_{6} \mathrm{O}_{4}(\mathrm{OH})_{4}\right]^{6+}$. The other of these complex ions has average $\mathrm{Bi}-\mathrm{Bi}$ distances of $3.50 \AA$, and must correspond to the ion with the largest number of O-groups, which is $\left[\mathrm{Bi}_{6} \mathrm{O}_{5}(\mathrm{OH})_{3}\right]^{5+}$.
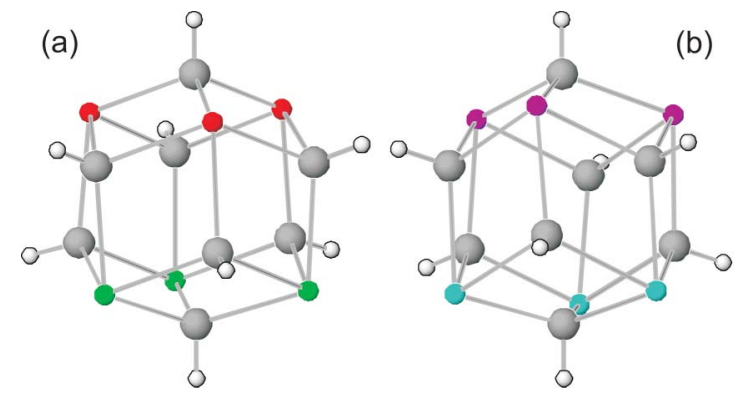

(b)

Fig. 7 Schematic drawing of the two complex Bi-ions, (a) $\left[\mathrm{Bi}_{6} \mathrm{O}_{4}(\mathrm{OH})_{4}\right]^{6+}$ and (b) $\left[\mathrm{Bi}_{6} \mathrm{O}_{5}(\mathrm{OH})_{3}\right]^{5+}$. Within the accuracy of the present neutron diffraction data, it was not possible to distinguish between $\mathrm{O}$-atoms and $\mathrm{OH}$-groups on the surfaces of the two complex Bi-octahedra in the model refinement. The atoms Bila, Bilb, O11, and $\mathrm{O} 12$, plus $\mathrm{O} 1$ and $\mathrm{O} 2$ form one of the complex Bi molecules (a). The atoms Bi2a, Bi2b, O21, and O22, plus $\mathrm{O} 1$ and $\mathrm{O} 2$ form the other complex Bi molecule (b). See section 4.3. for further details.

The average $\mathrm{Bi}-\mathrm{O}$ distance in the two complex ions is 2.33(1) $\AA$. In the ordered structure of $\left[\mathrm{Bi}_{6} \mathrm{O}_{4}(\mathrm{OH})_{4}(\mathrm{OTf})_{6}\right]-$ $\left(\mathrm{CH}_{3} \mathrm{CN}_{6}\right) \cdot 2 \mathrm{CH}_{3} \mathrm{CN}$, where OTf is the anion of triflic acid, trifluoromethanesulfonic acid, $\mathrm{CF}_{3} \mathrm{SO}_{3} \mathrm{H}$, the average $\mathrm{Bi}-\mathrm{OH}$ and $\mathrm{Bi}-\mathrm{O}$ distances are 2.40(4) $\AA$ and 2.16(4) $\AA$, respectively. ${ }^{18}$ The $\mathrm{Bi}-\mathrm{O}$ distances listed in Table 7 are thus within this range of distances. Refinement of the ratio between the two complex ions $\left[\mathrm{Bi}_{6} \mathrm{O}_{4}(\mathrm{OH})_{4}\right]^{6+}$ and $\left[\mathrm{Bi}_{6} \mathrm{O}_{5}(\mathrm{OH})_{3}\right]^{5+}$ gave the coefficients $0.54(1)$ and $0.46(1)$ respectively, and to obtain electro neutrality the coefficient of the $\mathrm{NO}_{3}$-ion would then be 5.54(1), corresponding to an occupancy of 1.85(1). This is in excellent agreement with the occupancy of 1.83(1) obtained in refinement of the occupancy of the $\mathrm{NO}_{3}$-ion.

\section{Summary and conclusion}

The structure found in the present work is described in the space group $R \overline{3}$ is build of a disordered packing of the two complex ions $\left[\mathrm{Bi}_{6} \mathrm{O}_{4}(\mathrm{OH})_{4}\right]^{6+}$ and $\left[\mathrm{Bi}_{6} \mathrm{O}_{5}(\mathrm{OH})_{3}\right]^{5+}$. In a $1: 1$ ratio of the ions the formula would be $\left[\mathrm{Bi}_{6} \mathrm{O}_{4}(\mathrm{OH})_{4}\right]_{0.5}\left[\mathrm{Bi}_{6} \mathrm{O}_{5}(\mathrm{OH})_{3}\right]_{0.5}\left(\mathrm{NO}_{3}\right)_{5.5}$. Disorder in the structure was also observed in diffuse X-ray scattering reported previously. ${ }^{10}$ The structure investigation of $\left[\mathrm{Bi}_{6} \mathrm{O}_{4}(\mathrm{OH})_{4}\right]\left(\mathrm{NO}_{3}\right)_{6},{ }^{10}$ assumed a $1: 1$ ratio of the two complex $\mathrm{Bi}$ ions, so a correct formula assignment for that sample ${ }^{10}$ should rather have been $\left[\mathrm{Bi}_{6} \mathrm{O}_{4}(\mathrm{OH})_{4}\right]_{0.5}\left[\mathrm{Bi}_{6} \mathrm{O}_{5}(\mathrm{OH})_{3}\right]_{0.5}\left(\mathrm{NO}_{3}\right)_{5.5}$ or $\left[\mathrm{Bi}_{6} \mathrm{O}_{4.5}\left(\mathrm{OH}_{3.5}\right]\left(\mathrm{NO}_{3}\right)_{5.5}\right.$, where the former indicates the existence of the two forms of ions while the latter just gives the average.

The present investigation suggests a ratio slightly different from the $1: 1$ ratio, and the composition of the sample investigated was thus $\left[\mathrm{Bi}_{6} \mathrm{O}_{4}(\mathrm{OH})_{4}\right]_{0.54(1)}\left[\mathrm{Bi}_{6} \mathrm{O}_{5}(\mathrm{OH})_{3}\right]_{0.46(1)}\left(\mathrm{NO}_{3}\right)_{5.54(1)}$. The deviation from the $1: 1$ ratio is possible as the two complex ions are an acid base pair where the equilibrium between the ions is $\mathrm{pH}$ dependent. Experimental conditions can be selected to produce either pure $\left[\mathrm{Bi}_{6} \mathrm{O}_{4}(\mathrm{OH})_{4}\right]^{6+}$ or pure $\left[\mathrm{Bi}_{6} \mathrm{O}_{5}(\mathrm{OH})_{3}\right]^{5+}$ containing basic Bi-nitrates, see Table 1, or both the ions are present as in this investigation.

It is not often that a structure contains two complex ions with almost the same composition, but with different ionic charges. In the present compound the two complex ions have almost the same composition, different charges and almost the same three dimensional shapes of the ions, which may explain the disordered packing of the ions in the fast growth mode.

\section{References}

1 A. F. Holleman, and E. Wiberg, Lehrbuch der Anorganischen Chemie, Walter de Gruyter \& Co, Berlin, 1971, p. 440.

2 G. Hägg, General and Inorganic Chemisty, John Wiley \& Sons, Inc, New York, 1969, p. 580.

3 F. Lazarini, Cryst. Struct Commun., 1979, 8, 69.

4 F. Lazarini, Acta Crystallogr., Sect. B: Struct. Crystallogr. Cryst. Chem., 1979, 35, 448.

5 B. Sundvall, Acta Chem. Scand., Ser. A, 1979, 33a, 219.

6 F. Lazarini, Acta Crystallogr., Sect. B: Struct. Crystallogr. Cryst. Chem., 1978, 34, 3169.

7 A. N. Christensen, M.-A. Chevallier, J. Skibsted and B. B. Iversen, J. Chem. Soc., Dalton Trans., 2000, 265.

8 A. N. Christensen, T. R. Jensen, N. V. Y. Scarlett, I. C. Madsen, J. C. Hanson and A. Altomare, Dalton Trans., 2003, 3278.

9 N. Henry, M. Evain, P. Deniard, S. Jobic, O. Mentré and F. Abraham, J. Solid State Chem., 2003, 176, 127.

10 N. Henry, O. Mentré, F. Abraham, E. J. MacLean and P. Roussel, J. Solid State Chem., 2006, 179, 3087.

11 P. Pascal, Nouveau traité de chimie minéral, Vol. XI, Masson \& Cie, Paris, 1958, p. 795.

12 A. N. Christensen, M. S. Lehmann and A. Wright, Acta Chem. Scand., 1982, A36, 789.

13 A. Boultif and D. Louër, J. Appl. Crystallogr., 2004, 37, 724.

14 J. W. Visser, J. Appl. Crystallogr., 1969, 2, 89.

15 J. Rodríguez-Carvajal, Physica, 1993, B192, 55.

16 V. Favre-Nicolin, R. Cerny, Materials Science Forum 443-444 (EPDIC8), 2004, 35.

17 G. M. Sheldrick, Acta Crystallogr., Sect. A: Found. Crystallogr., 2008, 64, 112.

18 L. Miersch, T. Rüfer, H. Lang, S. Schulze, M. Heitschold, D. Zahn and M. Mehring, Eur. J. Inorg. Chem., 2010, 4763. 